\title{
Tinjauan Yuridis Penggunaan Klausul Proteksi Diri Terhadap Akta Pernyataan Keputusan Rapat Perseroan Terbatas
}

\author{
Muhammad Ulinnuha \\ Pascasarjana Hukum Universitas Islam Indonesia Yogyakarta Indonesia \\ Jln. Cik Di Tiro No.1, Yogyakarta Indonesia \\ ulinmuhammad97@ymail.com
}

\begin{abstract}
The purpose of this study is to determine the actions that should be taken by a Notary in making a Resolution Deed of a Limited Liability Company and the use of a self-protection clause in making the Resolution Deed of a Limited Liability Company which may serve as a protective shield for a Notary. This study uses a normative juridical research method. The results conclude that in making the Resolution Deed of the General Meeting of Shareholders, the Notary must be able to thoroughly, carefully and properly carry out his duties and positions; practicing the principle of prudence, as the Resolution Deed of the General Meeting of Shareholders is an akten partij, which means the Notary needs only to record what the parties desire in the Deed without changing, subtracting and adding the contents of the Deed. The existence of a self-protection clause in a Resolution Deed of the General Meeting of Shareholders cannot automatically become a protector for the Notary when a problem occurs in the future, as regulated in Article 65 of Law No. 30 of 2004 on Notary Positions (UUJN) and its amendments. that the Notary must be responsible for every deed they make..
\end{abstract}

Key Words: Limited liability company; notary; resolution deed

\begin{abstract}
Abstrak
Tujuan penelitian ini untuk mengetahui tindakan seharusnya yang dilakukan Notaris dalam membuat Akta Pernyataan Keputusan Rapat Perseroan Terbatas dan penggunaan klausul proteksi diri dalam pembuatan Akta Pernyataan Keputusan Rapat Perseroan Terbatas dapat menjadi perlindungan terhadap Notaris. Penelitian ini menggunakan metode penelitian yuridis normatif. Hasil dari penelitian ini menyimpulkan bahwa di dalam membuat Akta Pernyataan Keputusan Rapat Umum Pemegang Saham Notaris harus benar-benar mampu menjalankan tugas dan jabatannya dengan baik dan selalu berprinsip hati-hati, karena Akta Pernyataan Keputusan Rapat Umum Pemegang Saham merupakan partij akten, Notaris hanya perlu mencatatkan apa yang dikehendaki oleh para pihak dalam akta tanpa merubah, mengurangi dan menambahkan isi dari akta tersebut. Adanya klausa proteksi diri dalam suatu Akta Pernyataan Keputusan Rapat Umum Pemegang Saham tidak bisa serta merta menjadi pelindung untuk Notaris ketika terjadi suatu permasalahan dikemudian hari, karena sudah diatur didalam Pasal 65 Undang-Undang Nomor 30 Tahun 2004 tentang Jabatan Notaris (UUJN) dan UU perubahannya bahwa Notaris harus bertanggungjawab atas setiap akta yang dibuat olehnya.
\end{abstract}

Kata-kata Kunci: Notaris; pernyataan keputusan rapat; perseroan terbatas 


\section{Pendahuluan}

Notaris merupakan pejabat umum yang secara khusus diberikan wewenang oleh undang-undang untuk membuat suatu alat bukti yang otentik (mempunyai kekuatan pembuktian yang sempurna). ${ }^{1}$ Profesi Notaris termasuk ke dalam profesi luhur seperti yang dimaksud oleh C.S.T kansil dan Christine S.T Kansil, yaitu suatu profesi yang pada hakekatnya merupakan suatu pelayanan pada masyarakat. ${ }^{2}$ Notaris bertanggungjawab atas keabsahan akta autentik yang dibuatnya dan jika ternyata terdapat cacat hukum sehingga akta tersebut kehilangan otentisitasnya serta merugikan pihak yang berkepentingan maka Notaris dapat dituntut untuk mengganti biaya, ganti rugi dan bunga. Mengenai tanggungjawab materiil pada akta yang dibuat dihadapan Notaris perlu ditegaskan bahwa dengan kewenangan Notaris dalam pembuatan akta tidak secara bebas karena pembuatan akta otentik hanya bisa dilakukan sesuai permintaan para pihak. ${ }^{3}$

Notaris bertanggungjawab atas semua aspek formalitas akta yang dibuat oleh atau dihadapannya. Terhadap isi akta yang merupakan kehendak para pihak sendiri, tidak semua kehendak para pihak harus dikabulkan. Perubahan UUJN Pasal 65 Tanggungjawab Notaris secara eksplisit, menyatakan bahwa Notaris bertanggungjawab atas setiap akta yang dibuatnya, meskipun protokol Notaris telah diserahkan atau dipindahkan kepada pihak penyimpan protokol Notaris. ${ }^{4}$ Berdasarkan Perubahan UUJN Pasal 38 ayat (3) huruf c mengatur tentang ketentuan isi akta Menegaskan bahwa isi akta yang merupakan kehendak dan keinginan dari para pihak yang berkepentingan datang menghadap Notaris. Dengan demikian isi akta tersebut merupakan kehendak atau keinginan para penghadap sendiri, bukan keinginan atau kehendak Notaris, melainkan Notaris hanya membingkainya dalam bentuk akta Notaris sesuai dengan UUJN. ${ }^{5}$

Berdasarkan kewenangan Notaris tersebut, maka akta notaris mempunyai kekuatan pembuktian yang sempurna sehingga dapat menjamin kepastian, ketertiban dan perlindungan hukum bagi pihak yang menginginkan kebenaran dan keadilan bagi mereka. Wewenang notaris tersebut merupakan wewenang yang ditentukan berdasarkan peraturan perundang-undangan yang dibentuk

\footnotetext{
hlm. 1

${ }^{1}$ M. Luthfan Hadi Darus, Hukum Notaris dan Tanggung Jawab Jabatan Notaris, UII Press, Yogyakarta, 2017,

${ }^{2}$ C.S.T. Kansil dan Christine S.T. Kansil, Pokok-Pokok Etika Profesi Hukum, Pradnya Paramita, Jakarta, 1997, hlm. 5 .

${ }_{3}^{3}$ Abdul Ghofur Anshori, Lembaga Kenotariatan Indonesia Prespektif Hukum dan Etika, UII Press, Yogyakarta, 2009, hlm. 47.

${ }^{4}$ Ibid., hlm. 44. 30.

${ }^{5}$ Habib Adjie, Merajut Pemikiran Dalam Dunia Notaris\& PPAT, Citra Aditya Bakti, Surabaya, 2010, hlm.
} 
oleh lembaga negara atau Pejabat Negara yang berwenang dan mengikat secara umum. ${ }^{6}$

Akta merupakan surat yang dibuat dihadapan pegawai yang berwenang untuk membuatnya menjadi bukti yang cukup bagi kedua belah pihak dan ahli warisnya maupun berkaitan dengan pihak lainnya sebagai hubungan hukum, tentang segala hal yang disebut di dalam surat itu sebagai pemberitahuan hubungan langsung dengan perihal pada akta itu. ${ }^{7}$ Sedangkan Akta Otentik itu sendiri adalah akta yang dibuat dalam bentuk yang ditentukan oleh UndangUndang, dibuat oleh atau dihadapan pegawai-pegawai umum yang berkuasa untuk itu, ditempat di mana akta itu dibuatnya. ${ }^{8}$

Perseroan terbatas adalah persekutuan yang berbentuk badan hukum, dimana badan hukum ini disebut dengan "perseroan". .9 Berdasarkan Pasal 1 ayat (2) Undang-Undang Nomor 40 Tahun 2007 menentukan bahwa organ perseroan terdiri dari Rapat Umum Pemegang Saham (RUPS), Direksi dan Dewan Komisaris. Organ-organ tersebut mempunyai fungsi dan tugas masing-masing, sesuai dengan ketentuan Undang-Undang Perseroan Terbatas, maupun anggaran dasar perseroan. Antara organ-organ perseroan tersebut satu sama lain, mempunyai hubungan organis maupun fungsional. Hubungan organis adalah hubungan yang berkaitan dengan pelaksanaan fungsi masing-masing organ sebagai penetap kebijakan, pelaksana kebijakan, pengawas atau pelaksanaan kebijakan dan lain-lain, maka perseroan mutlak memerlukan Direksi, Komisaris dan menyelenggarakan Rapat Umum Pemegang Saham (RUPS). Jika ditinjau dari tatanan normatif terdapat 2 jenis RUPS10, yaitu, RUPS Tahunan dan RUPS lainnya, ${ }^{11}$ kemudian dalam Pasal 78 ayat (4) Undang-Undang Perseroan Terbatas selanjutnya disingkat UUPT menjelaskan RUPS lainnya diadakan setiap waktu tergantung dari kebutuhan atau kepentingan perseroan, sedangkan RUPS Tahunan diadakan dalam jangka waktu paling lambat 6 bulan setelah tahun buku berakhir. ${ }^{12}$ RUPS lainnya dalam praktik juga dikenal dengan istilah Rapat Umum Pemegang Saham Luar biasa selanjutnya disingkat RUPS LB. Pembuatan risalah RUPS bersifat imperatif yang dimana setiap penyelenggaran RUPS "wajib"

19

${ }^{6}$ Rosjidi Ranggawidjaya, Pengantar Ilmu Perundang-Undangan Indonesia, Mandar Maju, Bandung, 1998, hlm.

7 Lubis Irwansyah, Syahnel Anhar, Lubis Muhammad Zuhdi, Profesi Notaris dan Pejabat Pembuat Akta Tanah, Edisi Kedua, Mitra Wacana Medika, Jakarta, 2018, hlm. 47

${ }^{8}$ Ibid., hlm. 48

${ }^{9}$ Kansil, Pokok-Pokok Hukum Perseroan Terbatas, Pustaka Sinar Harapan, Jakarta, 1996, hlm. 31

${ }^{10}$ Rapat Umum Pemegang Saham (RUPS), adalah organ perseroan yang memegang kekuasaan tertinggi dalam perseroan dan memegang segala wewenang yang tidak diberikan terhadap Direksi dan Komisaris. Lihat Pasal 1 ayat (4) Undang-Undang Nomor 40 Tahun 2007 tentang Perseroan Terbatas.

${ }^{11}$ Lihat Pasal 78 ayat (1) Undang-Undang Nomor 40 Tahun 2007 tentang Perseroan Terbatas

${ }^{12}$ Ibid., ayat (2) Undang-Undang Perseroan Terbatas 
dibuatkan risalahnya termasuk juga hal-hal yang termuat dalam Pasal 21 UUPT, RUPS yang tidak dibuat risalah rapatnya tentunya tidak sah dan dianggap tidak pernah ada serta mengakibatkan hal-hal yang diputusakan dan ditetapkan dalam RUPS tidak dapat dilaksanakan.

Penyelenggaraan RUPS tentunya merupakan hal yang penting untuk dilaksanakan dalam perseroan, disisi lain juga RUPS menjadi suatu wadah bagi pemegang sahamdalam menyampaikan hak suaranya untuk mengambil suatu keputusan atau kebijakan terkait jalannya suatu perseroan tersebut. Selain RUPS atau pengambilan keputusan pemegang saham yang terdapat dalam Pasal 78 UUPT, terdapat juga pengambilan keputusan pemegang saham yang mengikat diluar RUPS atau didalam praktik dikenal dengan istilah Circular Resolution atau Keputusan Sirkuler. Dasar hukum dari pengambilan Keputusan Sirkuler di luar RUPS diatur dalam Pasal 91 UUPT, dalam pasal tersebut menjelaskan bahwa penyelenggaran selain sebagaiman dimaksud dalam Pasal 78 UUPT ternyata terdapat suatu penyelenggaraan keputusan di luar RUPS yang juga memiliki kekuatan mengikat sama halnya RUPS yang dimaksud dalam Pasal 78 UUPT. Pengambilan keputusan di luar RUPS ini selanjutnya disebut Keputusan Sirkuler jika kita menafsirkan Pasal 91 di atas ternyata keputusan tersebut dilakukan tanpa diadakan RUPS secara fisik melainkan keputusan tersebut diambil dengan cara mengirimkan secara tertulis usul yang akan diputuskan kepada semua atau seluruh pemegang saham dan usulan tersebut harus disetujui secara tertulis oleh seluruh pemegang saham tanpa terkecuali, hal tersebut merupakan syarat mutlak dari penyelenggaraan keputusan rapat pemegang saham di luar RUPS yang memiliki kekuatan mengikat. Kekuatan mengikat menurut peneliti ini ialah keputusan yang mempunyai kekutan hukum yang sama dengan keputusan RUPS pada umumnya dalam hal ini yang termuat dalam Pasal 78 UUPT, mengikatnya keputusan sirkuler tersebut tentunya harus disetujui oleh semua pemegang saham. Kemudian dari hasil kesepakatan tertulis tersebut dibuatkan risalah rapat sirkuler kemudian dituangkan kedalam bentuk Akta Notaris yang didalam praktik pelaksanaan tugas jabatan notaris dikenal dengan Akta Pernyataan Keputusan Rapat (PKR).

Notaris dalam melaksanakan tugas jabatannya, seringkali mendapatkan masalah atas pembuatan Akta Pernyataan Keputusan Rapat (PKR). Permasalahan tersebut muncul ketika dalam pembuatan Akta PKR Notaris tidak hadir secara langsung yang akhirnya menimbulkan kerugian, baik bagi para pihak maupun notaris itu sendiri. Beberapa hal seperti identitas para pihak atau salah satu pihak yang dikemudian hari baru disadari bahwa identitas yang diberikan dihadapan notaris ternyata palsu atau dipalsukan, kemudian terkait keterangan yang 
disampaikan para penghadap tidak sesuai dengan kebenaranya, dan data atau dokumen yang digunakan sebagai dasar pembuatan akta Pernyataan Keputusan Rapat (PKR) ternyata tidak benar dan dipalsukan. Kasus-kasus ini kemudian menyeret Notaris, yang awal mulanya sebatas sebagai saksi, kemudian di tingkatkan sebagai tersangka, kemudian meningkat lagi menjadi terdakwa, kebanyakan di sebabkan adanya sengketa diantara internal orang-orang PT entah itu diantara pemegang dan atau para pengurus PT tersebut. ${ }^{13}$

Padahal seperti kita ketahui bersama bahwa hubungan hukum antara Notaris dengan penghadap bukanlah merupakan hubungan kontraktual antara satu pihak dengan pihak lainya, para penghadap datang ke Notaris atas kesadaran sendiri dan mengutarakan keinginan dihadapan Notaris yang kemudian dituangkan dalam bentuk akta notariil yang sesuai aturan hukum yang berlaku, maka tuntutan untuk perbuatan melawan hukum sesuai Pasal 1365 KUHPer tidak dapat dilakukan terhadap Notaris. ${ }^{14}$

Oleh karena itu wajar, guna untuk memperkuat perlindungan dirinya sendiri, dalam menjalankan tugas dan jabatan dengan baik dan benar sudah merupakan perlindungan diri yang tepat, akan tetapi untuk menambah perlindungan diri, notaris mencamtumkan suatu klausul perlindungan diri notaris dalam akta yang dibuatnya yang disebut dengan klausul proteksi diri. Adapun salah satu contoh klausul proteksi diri yang dimaksud, yaitu: "Bahwa para penghadap menyatakan, jika terjadi sengketa baik di dalam maupun di luar pengadilan, baik secara perdata dan pidana tidak akan melibatkan Notaris dan saksi-saksi dengan cara dan bentuk apapun." Sedangkan di dalam UUJN tidak mengatur penggunaan klausul proteksi diri, klausul proteksi diri sering dianggap sebagai klausul yang mampu melindungi notaris di dalam pembuatan akta Pernyataan Keputusan Rapat (PKR), hal ini sering digunakan dalam pelaksanaan tugas jabatan notaris, akan tetapi hal tersebut belum diatur secara jelas didalam UUJN, terkhusus mengenai klausul proteksi diri melainkan penggunaan klausul ini hanya kebiasaan yang digunakan berulang kali oleh notaris didalam menjalankan tugas jabatannya.

Untuk mengatasi masalah tersebut notaris menggunakan klausul proteksi diri agar dikemudian hari jika terjadi permasalahan yang mengakibatkan kerugian, notaris tidak terjerat atau terlepas dari permasalahan yang timbul tersebut, maka notaris menambahkan klausul proteksi diri dengan harapan notaris dapat terlepas dari tuntutan dari para pihak jika akta yang dibuat oleh

\footnotetext{
13 Mulyoto, Pertanggung Jawaban Notaris-PPAT Dalam Menjalankan Tugas Jabatannya, Cakrawala Media, Yogyakarta, 2010, hlm. 18

${ }^{14}$ Habib Adjie, Meneropong Khasanah Notaris dan PPAT, Op. Cit., hlm. 14
} 
notaris ternyata menimbulkan kerugian. sedangkan didalam menjalankan tugasnya, yang menjadi alat perlindung diri notaris sendiri adalah bagaimana dia mengamalkan prinsip notaris yang telah diatur didalam UUJN itu sendiri, dalam melaksanakan tugas dan jabatannya notaris harus bertindak secara profesional dan amanah, dalam prakteknya penggunaan klausul proteksi diri tidak diatur dalam UUJN sehingga tidak adanya larangan notaris dalam penggunaan kluasul proteksi diri, oleh karena itu sampai sekarang ini klausul proteksi diri masih banyak digunakan oleh notaris gunamelindungi dirinya sendiri dengan kata lain notaris merasa lebih aman jika mencantumkan klausul proteksi diri pada bagian akhir akta.

Berangkat dari permasalahan yang sudah dipaparkan diatas penulis ingin melakukan penelitian tentang sejauhmana penggunaan klausul proteksi diri menjadi jaminan perlindungan hukum dalam pembuatan akta Pernyataan Keputusan Rapat (PKR) Perseroan Terbatas. Sehingga penulis, menulis penelitian dengan judul “Tinjauan Yuridis Penggunaan Klausul Proteksi Diri Terhadap Akta Pernyataan Keputusan Rapat Perseroan Terbatas".

\section{Rumusan Masalah}

Berdasarkan latar belakang yang telah diuraikan di atas, maka rumusan masalah dalam penelitian ini yaitu pertama, bagaimana tindakan seharusnya yang dilakukan Notaris dalam pembuatan Akta Pernyataan Keputusan Rapat Perseroan Terbatas? Kedua, apakah penggunaan klausul proteksi diri dalam pembuatan Akta Pernyataan Keputusan Rapat Perseroan Terbatas dapat menjadi perlindungan terhadap Notaris?

\section{Tujuan Penelitian}

Berdasarkan permasalahan yang telah di rumuskan diatas, maka tujuan dari penelitian ini adalah untuk mengetahui tindakan seharusnya yang dilakukan Notaris dalam membuat Akta Pernyataan Keputusan Rapat Perseroan Terbatas dan penggunaan klausul proteksi diri dalam pembuatan Akta Pernyataan Keputusan Rapat Perseroan Terbatas dapat menjadi perlindungan hukum bagi Notaris.

\section{Metode Penelitian}

Metode pendekatan yang digunakan adalah metode penelitian yuridis normatif, penelitian yuridis normatif ialah suatu penelitian dengan cara meneliti bahan pustaka atau bahan sekunder yang terdiri dari peraturan perundang- 
undangan dan literatur-literatur hukum. ${ }^{15}$ Dan juga dibantu dengan hasil wawancara dengan beberapa Notaris, dan melihat dari pandangan-pandangan dan doktrin-doktrin yang berkembang di dalam ilmu hukum, pendekatan permasalahan ini dapat dijadikan pisau analisis untuk menjawab permasalahan mengenai penelitian yang penulis sedang teliti.

\section{Hasil Penelitian dan Pembahasan}

\section{Tindakan Notaris dalam Pembuatan Akta Pernyataan Keputusan Rapat Perseroan Terbatas}

Notaris memiliki peran yang sangat penting dalam kehidupan masyarakat, terutama dalam hal kewenangannya terhadap pembuatan akta autentik. Akta autentik yang dibuat oleh atau dihadapannya memiliki kekuatan yang sempurna jika dibandingkan dengan surat dibawah tangan. Sehingga apabila ada pihak yang mengajukan Akta Autentik sebagai bukti dipengadilan dalam suatu perkara, maka hakim harus menerima dan menganggap apa yang tertera didalam akta tersebut benar sungguh terjadi, dan Akta Autentik itu harus selalu dianggap benar kecuali dapat dibuktikan sebaliknya. ${ }^{16}$ Hal ini berbeda dengan akta di bawah tangan yang memiliki kekuatan pembuktian sempurna apabila semua pihak mengakuinya dan menyatakan benar serta tidak ada pihak didalam akta yang menyangkal. Jika ada salah satu pihak yang menyangkal terhadap isi dari suatu akta, maka beban pembuktian diserahkan kepada pihak yang menyangkal terhadap akta tersebut dan penilaian penyangkalan atas bukti diserahkan kepada hakim. ${ }^{17}$ Sifat autentik suatu akta inilah yang menjadi alasan mengapa notaris sangat dibutuhkan oleh masyarakat.

Menurut Pasal 1868 KUHPerdata, akta autentik merupakan akta menurut bentuk yang ditentukan oleh undang-undang, dibuat oleh atau di hadapan pegawai-pegawai umum yang berwenang untuk itu di tempat akta itu dibuat. Dalam menjalankan jabatannya Notaris terikat dengan peraturan UUJN ${ }^{18}$ dan kode etik jabatannya yang dibuat oleh Organisasi Notaris yang dalam hal ini adalah Ikatan Notaris Indonesia (untuk selanjutnya disebut INI).

Perseroan terbatas pada dasarnya didirikan berdasarkan perjanjian, yang didasarkan kesepakatan bersama serta memiliki tujuan yang sama, sehingga berdasarkan kehendak yang sama tersebut mereka membentuk suatu badan

\footnotetext{
${ }^{15}$ Soerjono Soekanto, Pengantar Penelitian Hukum, UI Press, Jakarta, 1986, hlm. 13

16 Yayasan Lembaha Bantuan Hukum Indonesia, Panduan Bantuan Hukum di Indonesia, cet. 2, Yayasan Obor Indonesia, Jakarta, 2007, hlm. 135.

17 M. Ali Boediarto, Kompilasi Kaidah Hukum Putusan Mabkamah Agung: Hukum Acara Perdata Masa Setengah Abad, Swara Justitia, Jakarta, 2005, hlm. 145-146.

18 Pasal 15 Undang-Undang Nomor 30 Tahun 2004 tentang Jabatan UUJN perubahan Undang-Undang Nomor 2 Tahun 2014 tentang Jabatan Notaris
} 
usaha berbentuk perseroan terbatas. Oleh karena perseroan terbatas terbentuk atas dasar perjanjian, maka tidak bisa dilepaskan dari ketentuan syarat sah perjanjian yang diatur dalam Pasal 1320 KUHPer. ${ }^{19}$ Adanya suatu perjanjian tentu tidak bisa juga dilepaskan dari peran penting Notaris didalamnya, karena Notaris adalah pejabat yang telah ditunjukkan oleh Undang-undang untuk membuat akta autentik dan menjadi syarat utama dalam pembentukan suatu perseroan terbatas harus memiliki akta pendirian yang dibuat oleh Notaris. Dalam bidang hukum Perseroan Terbatas (untuk selanjutnya disebut PT), peranan Notaris diatur dalam Undang-Undang Nomor 40 Tahun 2007 (untuk selanjutnya disebut UUPT). Perseroan Terbatas sebagai subjek hukum yang berupa badan hukum lahir melalui proses hukum (created by legal process) yang pendiriannya harus dinyatakan dengan Akta Notaris. ${ }^{20}$ Notaris memiliki peran tidak hanya dalam pendirian PT melainkan juga dalam banyak kegiatan yang dimana PT juga membutuhkan jasa Notaris, dalam hal ini membuat Berita Acara RUPS, maupun melakukan pemberitahuan sertapersetujuan perubahan anggaran dasar kepada Menteri Hukum dan Hak Asasi Manusia Republik Indonesia. ${ }^{21}$

Akta pendirian PT dan Akta perubahan anggaran dasar PT merupakan Akta yang harus dimuat dalam bentuk autentik melalui Akta Notaris. ${ }^{22}$ Pendirian PT dengan Akta Notaris merupakan syarat yang diatur dalam Pasal 7 ayat (1) UUPT. Selain itu, alasan mengapa Akta Pendirian harus berbentuk Akta Notaris dikarenakan Akta tersebut berfungsi sebagai alat bukti dan bersifat solemnitas causa, yaitu apabila tidak dibuat dalam Akta Notaris maka Akta Pendirian Perseroan itu tidak memenuhi syarat sehingga tidak dapat diberikan pengesahan oleh Menteri. ${ }^{23}$ Selain Akta Pendirian, perubahan anggaran dasar PT juga diwajibkan dibuat dalam bentuk Akta autentik. Perubahan anggaran dasar dapat dinyatakan dalam 3 bentuk Akta Notaris yaitu Akta Risalah Rapat atau/Berita Acara Rapat (untuk selanjutnya disebut BAR), Akta Pernyataan Keputusan Rapat diluar RUPS atau Sirkuler Rapat (untuk selanjutnya disebut PKR), dan Akta Pernyataan Keputusan Para Pemegang Saham (untuk selanjutnya disebut Akta PKPPS). Dalam BAR, Notaris turut hadir pada penyelenggaraan RUPS dalam kedudukanya sendiri. Notaris menyaksikan sendiri jalannya RUPS dan menuangkankannya dalam berita acara. Sedangkan dalam pembuatan Akta PKR, Notaris tidak hadir ketika RUPS diadakan. Notaris membuat Akta PKR

19 Binoto Nadapdap, Hukum Perseroan Terbatas (Berdasarkan Undang-Undang No. 40 Tabun 2007), Jala Permata Aksara, Jakarta, 2016, hlm. 4-5.

${ }^{20}$ Lihat Pasal 7 ayat (1) UUPT

${ }^{21}$ Lihat Pasal 21 ayat (1, 2, 3, dan 4) UUPT

${ }^{22}$ Lihat Pasal 7 ayat (1) j.o. Pasal 21 ayat (4) UUPT

${ }^{23}$ M. Yahya Harahap, Hukum Perseroan Terbatas, Sinar Grafika, Jakarta, 2009, hlm. 161. 
berdasarkan notulensi RUPS yang dibuat di bawah tangan disertai dengan buktibukti pendukung. Sementara itu, dalam Akta PKPPS, RUPS tidak diselenggarakan oleh PT. Namun dibuat dalam bentuk pernyataan tertulis yang ditandatangani oleh seluruh pemegang saham yang menyetakan persetujuannya terhadap suatu usul. Kehadiran Notaris dalam RUPS mempengaruhi jenis Akta yang dibuat.

Terdapat 2 jenis Akta yaitu Akta relaas dan Akta partij. Akta relaas diartikan sebagai Akta yang berisi uraian Notaris yang dilihat, disaksikan Notaris itu sendiri atas permintaan para pihak agar tindakan atau perbuatan para pihak dituangkan ke dalam bentuk Akta Notaris. Sementara itu, Akta partij dapat diartikan sebagai Akta yang berisikan uraian atau keterangan, pernyataan para pihak yang diceritakan di hadapan Notaris. Para pihak berkeinginan agar uraian atau keterangannya dituangkan dalam bentuk Akta Notaris. ${ }^{24}$ BAR termasuk dalam golongan Akta relaas karena Notaris menyaksikan sendiri jalannya RUPS atas undangan rapat dari Direksi PT dan menuangkannya dalam bentuk berita acara, BAR merupakan Akta yang dibuat oleh Notaris.

Akta PKR dan Akta PKPPS merupakan Akta partij yang mana Notaris tidak hadir dalam kedudukannya pada saat RUPS dilangsungkan atau memang tidak pernah diadakannya RUPS dalam hal pembuatan Akta PKPPS karena keputusannya diambil berdasarkan penandatanganan sebagai bentuk persetujuan dari circular letter. Kedua Akta ini merupakan Akta yang dibuat dihadapan Notaris, dimana terdapat pihak yang ditunjuk dalam RUPS maupun berdasarkan circular letter untuk menuangkan keputusan tersebut dalam bentuk Akta Notaris. Pihak tersebut akan menjadi penghadap yang datang kepada Notaris untuk menuangkan keputusan RUPS atau circular letter dalam bentuk Akta autentik demi memenuhi peraturan perundang-undangan yang berlaku. Setelah dituangkan dalam bentuk Akta Notaris, selanjutnya dilakukan pendaftaran secara online melalui SABH untuk memberitahukan perubahannya kepada Menteri atau mendapatkan persetujuan dari Menteri terhadap perubahan anggaran dasar tersebut dilengkapi dengan bukti pendukungnya. Isi dari Akta Pernyataan Keputusan Rapat Umum Pemegang Saham Perseroan Terbatas, pada umumnya adalah tentang perubahan Anggaran Dasar atau Hasil Rapat Tahunan Perseroan.

Perubahan Anggaran Dasar Perseroan tertentu seperti yang disebutkan diatas harus mendapatkan persetujuan dari Menteri. ${ }^{25}$ Sedangkan Perubahan Anggaran Dasar selain dari yang telah ditentukan dalam Pasal 21 ayat (2) UUPT

${ }^{24}$ G.H.S. Lumban Tobing, Peraturan Jabatan Notaris, Erlangga, Jakarta 1983, hlm. 51.

${ }^{25}$ Lihat Pasal 21 ayat (1) UUPT 
cukup dengan pemberitahuan kepada Menteri.26 Setiap Perubahan Anggaran Dasar harus dimuat atau dinyatakan dalam Akta Notaris, baik berbentuk Berita Acara RUPS atau Akta Pernyataan Keputusan Rapat Umum Pemegang Saham. ${ }^{27}$ Adanya ketentuan ini membuat kehadiran Notaris didalam suatu RUPS tidak selalu dibutuhkan, karena hasil keputusan RUPS tetap bisa dimuat didalam Akta Notaris meski tanpa Kehadiran Notaris saat RUPS. Perubahan Anggaran Dasar yang tidak dimuat dalam Akta Berita Acara RUPS yang dibuat oleh Notaris memiliki jangka waktu pengajuan selama 30 hari sejak keputusan RUPS harus dimuat didalam Akta Notaris atau Akta Pernyataan Keputusan Rapat Umum Pemegang Saham sebagaimana yang dijelasakan didalam Pasal 21 ayat (5) UUPT jika Perubahan Anggaran Dasar tersebut tidak dinyatakan dalam akta notaris permohonan atau persetujuannya tidak dapat diterima atau diajukan kepada Menteri28, Dalam hal pembuatan Akta Pernyataan Keputusan Rapat Umum Pemegang Saham, Notaris berhak memastikan risalah dibawah tangan tersebut telah ditandatangi oleh setidaknya pimpinan rapat dan minimal 1 orang anggota rapat dan didalamnya terdapat kuasa kepada salah seorang yang hadir didalam rapat untuk menunjukkan apa yang telah dihasilkan didalam rapat. ${ }^{29}$

Selain itu, Notaris harus meminta dan melihat dokumen-dokumen penting kepada penghadap seperti Kartu Tanda Penduduk, Kartu Keluarga, Buku Nikah, dan NPWP, hal ini untuk memastikan bahwa pengahadap dan yang hadir didalam rapat adalah benar mereka yang telah diatur didalam anggaran dasar perseroan, Notaris harus memastikan kesesuaian tanda tangan dan Notaris juga harus memahami daftar hadir peserta rapat sesuai dengan kepemilikan saham, hal ini untuk memastikan kewenangan membuat keputusan dalam RUPS. 30

Proses pembuatan Akta Pernyataan Keputusan Rapat Umum Pemegang Saham, tidak serta merta ketika semua berkas dokumen dan identitas penghadap lengkap secara formil, Notaris langsung memuatkan Akta PKR, dalam hal ini Notaris harus benar-benar memahami perannya dalam menjalankan tugas dan jabatannya agar sejalan dengan peraturan perundang-undangan. Notaris harus berhati-hati memeriksa formalitas dari semua kelengkapan dokumen tersebut, bahkan notaris harus benar-benar melihat quorum pemegang saham minimal 75\% dalam mengambil keputusan. Selain dari itu Notaris harus memahami dan mengetahui apakah tata cara pelaksanaan RUPS yang dilakukan perseroan

${ }^{26}$ Lihat Pasal 21 ayat (3) UUPT

${ }^{27}$ Lihat Pasal 21 ayat (4 dan 5) UUPT

${ }^{28}$ Lihat Pasal 21 ayat (9) UUPT

${ }^{29}$ Hasil wawancara dengan B. Hendri Susanto, Notaris dan PPAT di Yogyakarta, Pada 16 September 2020 pada Pukul 13.00 WIB.

${ }^{30}$ Hasil wawancara dengan Hendrik Budi Untung Notaris dan PPAT di Yogyakarta, Pada 19 September 2020 pada Pukul 09.00 WIB. 
berjalan sesuai dengan peraturan perundang-undangan. Oleh sebab itu penghadap yang hadir dihadap Notaris haruslah orang yang ikut serta, menyaksikan secara langsung, dan mendengarkan secara langsung bagaimana pelaksanaan RUPS. ${ }^{31}$

Pelaksanaan RUPS perseroan telah diatur didalam Undang-undang Perseroan Terbatas, dalam quorum kehadiran pemegang saham selain diatur dari UUPT juga harus dilihat bagaimana ketentuan yang diatur didalam Anggaran Dasar Perseroan. Pasal 77 ayat (2) UUPT menyebutkan "Persyaratan kuorum dan persyaratan pengambilan keputusan adalah persyaratan sebagaimana diatur dalam undang-undang ini dan/atau sebagaimana diatur dalam anggaran dasar Perseroan". Oleh karena itu Notaris harus benar-benar memahami bagaimana tata cara dan persyaratan pelaksanaan RUPS yang diatur oleh UUPT maupun ketentuan yang diatur didalam Anggaran Dasar Perseroan sebelum membuatkan suatu akta Pernyataan Keputusan Rapat Umum Pemegang Saham. Meskipun semua dokumen lengkap namun terdapat cacat dalam pelaksanaan RUPS Notaris berhak untuk menolak membuatkan Akta Pernyataan Keputusan Rapata Umum Pemegang Saham. ${ }^{32}$

\section{Perlindungan bagi Notaris Melalui Penggunaan Klausul Proteksi Diri dalam Pembuatan Akta Pernyataan Keputusan Rapat Perseroan Terbatas}

Akta Pernyataan Keputusan Rapat Umum Pemegang Saham perseroan adalah akta partij yang dibuat oleh Notaris, notaris membuat berdasarkan apa yang ditunjukkan atau dibawa oleh penghadap dihadapannya, Sedangkan dalam hal terjadi sengketa, maka kebenaran tersebut terhadap pihak ketiga memerlukan pembuktian materil yang diserahkan kepada pertimbangan dan keputusan hakim.

Isi dari Akta Pernyataan Keputusan Rapat Umum Pemegang Saham itu pada intinya berisi tentang segala sesuatu yang dibicarakan dan diputuskan didalam Rapat Umum Pemegang Saham (RUPS) yang diikuti, disaksikan dan didengar secara langsung oleh penandatangan (penghadap) akta Pernyataan Keputusan Rapat Umum Pemegang Saham, yang dalam hal ini biasanya ketua atau pimpinan rapat itu sendiri yang juga merangkap selaku salah seorang direksi perseroan tersebut. Pimpinan Rapat Umum atau orang yang menerima kuasa menyerahkan notulen atau risalah rapat umum pemegang saham tersebut kepada Notaris yang kemudian dimuatkan menjadi akta Pernyataan Keputusan Rapat Umum Pemegang Saham (Akta Autentik). Sehingga pada hakikatnya yang

${ }^{31}$ B. Hendri Susanto Notaris dan PPAT di Yogyakarta, Pada 16 September 2020 pada Pukul 13.00 WIB

${ }^{32} \mathrm{Ibid}$ 
menyatakan adanya keputusan-keputusan RUPS tersebut adalah orang atau pihak yang menerima kuasa atau penandatangan akta yang sesuai dengan Risalah RUPS. Pernyataan Keputusan Rapat Umum Pemegang Saham merupakan partijk akten (akta pratijk) yang dibuat "di hadapan" Notaris sebagaimana dijelaskan didalam Pasal 21 ayat (5) UUPT "Perubahan anggaran dasar yang tidak dimuat dalam akta berita acara rapat yang dibuat notaris harus dinyatakan dalam akta notaris paling lambat 30 hari terhitung sejak tanggal keputusan RUPS."33 Tapi dalam pertanggungjawabannya, Notaris hanya bertanggungjawab atas isi akta dari keterangan para penghadap.

Berdasarkan Pasal 38 ayat (3) huruf c UUJN Perubahan, menegaskan bahwa isi akta yang merupakan kehendak dan keinginan dari para pihak yang berkepentingan yang datang menghadap Notaris. Dengan demikian isi akta tersebut merupakan kehendak atau keinginan para penghadap sendiri, bukan keinginan atau kehendak Notaris, melainkan Notaris hanya membingkainya dalam bentuk akta Notaris sesuai dengan UUJN. ${ }^{44}$ Penyelenggaraan RUPS atau pengambilan keputusan pemegang saham selain yang terdapat dalam Pasal 78 UUPT, terdapat juga pengambilan keputusan pemegang saham yang mengikat diluar RUPS atau didalam praktik pelaksanaan tugas jabatan notaris dikenal dengan istilah Circular Resolution atau Keputusan Sirkuler. Dasar hukum dari pengambilan Keputusan Sirkuler di luar RUPS diatur dalam Pasal 91 UUPT, yang penjelasannya adalah: ${ }^{35}$

"pemegang saham dapat juga mengambil keputusan yang mengikat di luar RUPS dengan syarat semua pemegang saham dengan hak suara menyetujui secara tertulis dengan menandatangani usul yang bersangkutan."

Dalam penjelasan yang telah dipaparkan diatas dapat ditafsirkan bahwa penyelenggaran selain sebagaiman dimaksud dalam Pasal 78 UUPT ternyata terdapat suatu penyelenggaraan keputusan di luar RUPS yang juga memiliki kekuatan mengikat sama halnya RUPS yang dimaksud dalam Pasal 78 UUPT. Pengambilan keputusan di luar RUPS ini selanjutnya disebut Keputusan Sirkuler jika kita menafsirkan Pasal 91 diatas ternyata keputusan tersebut dilakukan tanpa diadakan RUPS secara fisik melainkan keputusan tersebut diambil dengan cara mengirimkan secara tertulis usul yang akan diputuskan kepada semua atau seluruh pemegang saham dan usulan tersebut harus disetujui secara tertulis oleh seluruh pemegang saham tanpa terkecuali, hal tersebut merupakan syarat mutlak dari penyelenggaraan keputusan rapat pemegang saham di luar RUPS yang

\footnotetext{
33 Pasal 21 ayat (5) UUPT

34 Habib Adjie, Sekilas Dunia Notaris dan PPAT Indonesia, Mandar Maju, Bandung, 2009, hlm. 30

35 Pasal 91 UUPT
} 
memiliki kekuatan mengikat. Kekuatan mengikat menurut peneliti ini ialah keputusan yang mempunyai kekutan hukum yang sama dengan keputusan RUPS pada umumnya dalam hal ini yang termuat dalam Pasal 78 UUPT, mengikatnya keputusan sirkuler tersebut tentunya harus disetujui oleh semua pemegang saham. Kemudian dari hasil kesepakatan tertulis tersebut dibuatkan risalah rapat sirkuler kemudian dituangkan kedalam bentuk Akta Notaris yang didalam praktik pelaksanaan tugas jabatan notaris dikenal dengan Akta Pernyataan Keputusan Rapat (PKR).

Pada dasarnya Akta Pernyataan Keputusan Rapat Umum Pemegang Saham adalah partij akten (Akta Penghadap), selama akta yang dibuat oleh Notaris sesuai dengan risalah yang pengahadap bawa kepada Notaris itu akan menjadi perlindungan hukum bagi notaris sendiri tanpa harus adanya klausul proteksi diri didlam akta tersebut, adanya klausul proteksi diri dalam suatu akta itu menjadi hal yang sah saja, karena memang tidak diatur secara eksplisit terhadap klausul ini, namun untuk pertanggung jawaban hukumnya, ada atau tidaknya klausul proteksi diri Notaris tetap harus bertanggung jawab atas setiap akta yang dibuatnya ${ }^{36}$, terlebih akta yang dibuatnya ternyata terdapat cacat formil dan/atau mengakibatkan suatu kerugian bagi pemegang saham atau PT tersebut maka notaris yang bersangkutan dapat dimintai pertanggungjawaban, hal tersebut juga dapat menjadi dasar bagi para pihak untuk mengajukan suatu gugatan kepegadilan jika hal tersebut memang dapat dibuktikan atau unsur yang terdapat dalam Pasal 1365 KUHPerdata terpenuhi dan dapat dibuktikan.

Notaris disini memiliki tugas selaku pejabat umum untuk membuat atau memformulasikan kehendak para pihak ke dalam bentuk akta autentik sebagaimana termuat dalam Pasal 38 ayat (3) UUJN yang menjelaskan akta merupakan kehendak para pihak yang berkepentingan, selain itu notaris disini jika ditinjau dari segi manfaat jabatan notaris dapat dipersamakan dengan tugas hakim yaitu sama-sama memberikan keadilan bagi para pihak yang tetuang dalam akta, dikarenakn notaris disini tidak diperbolehkan berpihak atau memihak salah satu pihak melainkan harus bersikap netral sebagaimana termuat dalam Pasal 16 ayat (1) huruf a UUJN, notaris selaku pejabat umum juga memiliki ketentuan yan dimana sangat ketat dalam hal ini notaris tidak diperbolehkan menjadi saksi maupun sebagai pihak yang berkepentingan pada akta yang dibuatnya ${ }^{37}$, karena dapat mengakibatkan akta tersebut mempunyai kekuatan pembuktian sebagai akta di bawah tangan..$^{38}$ Sedangkan jika ditinjau dari sifat

${ }^{36}$ Hasil wawancara dengan Hendrik Budi Untung, Notaris dan PPAT di Yogyakarta, Pada 19 September 2020 pada Pukul 09.00 WIB.

${ }^{37}$ Lihat Pasal 52 ayat (1) Undang-Undang Nomor 30 Tahun 2004 tentang Jabatan Notaris

${ }^{38}$ Ibid., Pasal 52 ayat (3) 
pembuktian dari Akta autentik yang dibuat oleh notaris terdiri atas 3 jenis yaitu, Kekuatan pembuktian Lahiriah, ${ }^{39}$ yaitu kekuatan pembuktian yang didasarkan atas keadaan lahir dari akta, artinya bahwa suatu surat yang kelihatannya seperti akta, harus diterima, dianggap, dan diperlakukan sebagai akta sampai dapat dibuktikan sebaliknya.

Pembuktian lahiriah ini menekankan bahwa sebuah akta otentik secara fisik mempunyai kekuatan untuk membuktikan sendiri keabsahannya sebagai akta otentik, jika para pihak mengingkari atau menyangkal akta otentik tersebut bukan sebagai akta otentik maka pihak tersebut dipengadilan harus membuktikannya sesuai dengan Asas Actori Incumbit Onus Probandito dalam hal ini beban pembuktian dalam perkara perdata melekat bagi para pihak yang berperkara, hal tersebut sesuai dengan asas beban pembuktian dalam perkara perdata dan juga harus membuktikannya lewat Pasal 1368 KUHPerdata mengenai akta autentik; Kekuatan pembuktian Formil, ${ }^{41}$ yaitu kekuatan pembuktian akta autentik adalah suatu pembuktian yang didasarkan atas kebenaran dari apa yang diurakan oleh pejabat yang berwenang dalam akta autentik tersebut, mengenai kebenaran tanggal dan waktu akta dibuat, kebenaran tanda tangan yang terdapat dalam akta serta identitas para pihak yang termuat dalam akta. Pembuktian akta ini menjamin kebenaran atas apa yang ada dan tertuang didalam akta, mengenai pernyataan-pernyataan serta tanda tangan para pihak yang menghadap/hadir. Sedangkan kekuatan pembuktian Materil yaitu, ${ }^{42}$ yang didasarkan atas benar atau tidaknya isi dari pernyataan yang ditanda tangani dalam sebuah akta, bahwa pertistiwa hukum yang dinyatakan dalam akta autentik benar-benar terjadi dan dikatan dihadapan notaris, sehingga dapat memberikan kepastian atas materi akta yang dibuat tersebut benar-benar merupakan kehendak para pihak yang diformulasikan kedalam akta tersebut.

Jika ditinjau dari bentuk pertanggungjawaban bagi Notaris berdasarkan Pasal 65 Undang-Undang Nomor 2 Tahun 2014 UUJN Perubahan menyatakan bahwa Notaris, Notaris Pengganti, dan Pejabat Sementara Notaris bertanggung jawab atas setiap Akta yang dibuatnya meskipun Protokol Notaris telah diserahkan atau dipindahkan kepada pihak penyimpan Protokol Notaris. ${ }^{43}$ Notaris tidak bertanggung jawab atas kelalaian dan kesalahan isi akta

39 Yosi Andika Mulyadi, "Kekuatan Pembuktian Akta Otentik Yang dibuat dihadapan Notaris dalam perkara pidana”, Tesis Pasca Sarjana Magister Kenotariatan Universitas Gadjah Mada Yogyakarta, 2016, hlm 26.

${ }^{40}$ https://m.hukumonline.com/berita/baca/lt5d08d3e8227c9/singgung-asas-i-actori-incumbit-onusprobandi-i-kpu-bantah-dalil-pemohon-sengketa-pilpres/. diakses pada 25 Sep 2020 pada pukul 20:38 WIB.

${ }^{41}$ Yosi Andika Mulyadi, Kekuatan Pembuktian Akta, Op. Cit., hlm. 26

${ }^{42}$ Ibid., hlm. 7

43 Lihat Pasal 65 Undang-Undang Nomor 2 Tahun 2014 tentang Perubahan atas Undang-Undang Nomor 30 Tahun 2004 tentang Jabatan Notaris. 
yang telah dibuat dihadapannya, melainkan notaris hanya bertanggung jawab bentuk formal akta autentik sesuai yang diisyaratkan oleh undang-undang. Bentuk tanggung jawab notaris selaku pejabat umum yang berhubungan dengan kebenaran materil Pertama Tanggung jawab notaris secara perdata terhadap kebenaran materil akta yang dibuatnya. Kedua Tanggung jawab notaris berdasarkan peraturan jabatan notaris terhadap kebenaran materil dalam akta yang dibuatnya, dan Ketiga tanggung jawab notaris dalam menjalankan tugas jabatannya berdasarkan kode etik notaris. Jika obyek yang menjadi sengketa dalam hal ini dinjau dari segi perdata yang dimana lazim terjadi dalam praktek dalam hal ini obyek yang menjadi sengketa yaitu Akta Pernyataan Keputusan Rapat Umum Pemegang Saham atau yang dikenal Sirkuler Resolution (Akta KPR) Berdasarkan pemaparan tersebut diatas jika salah satu pihak menyangkal atau mengingkari perbuatan hukum yang tertuang dalam akta tersebut maka para pihak diberikan asas beban pembuktian dalam perkara perdata dalam hal ini barang siapa yang mendalilkan maka para pihak harus membuktikan atau asas ini dikenal dengan istilah Actori Incumbit Onus Probandi. Lebih lanjut pemaparan yang telah peneliti paparkan dapat ditafsirkan bahwa jika dinjau dari segi pembuatannya dalam hal ini terpenuhin unsur akta autentik Pasal 1368 KUHPerdata Jo Pasal 38 UUJN serta pengambilan Keputusan Sirkuler di luar RUPS dibuat berdasarkan kententuan Pasal 91 UUPT dalam hal ini akta tersebut telah dibuat dihadapan pejabat yang berwenang serta bentuk dari akta tersebut telah terpenuhi menurut ketentuan tersebut maka akta yang dibuat tersebut merupakan akta autentik serta jika ditinjau dari segi kekuatan pembuktian dari segi Lahiriah, Formil dan Materil akta notaris maka ada atau tidaknya suatu klausul proteksi diri yang dibuat atau dimasukkan dalam akta yang dibuat oleh notaris maka notaris tersebut tidak dapat dimintai pertanggungjawaban jika terjadi suatu kerugian terlebih lagi jika kerugian tersebut ditimbulkan dari para pihak sendiri, karena tugas dari notaris disini hanya diberikan kewenangan hanya sebatas tuntutan dari segi formilnya saja dalam hal ini pembuatan akta tersebut harus sesuai dengan peraturan perundang-undangan yang berlaku. Berbeda halnya jika akta yang dibuatnya ternyata cacat dari segi formil atau dalam artian akta tersebut memiliki kekuatan pembuktian hanya sebagai akta dibawah tangan dan jika menimbulkan kerugian para pihak dapat menuntut ganti rugi sebagaimana termuat dalam Pasal 52 ayat (3) Undang-Undang Nomor 30 Tahun 2004 tentang Jabatan Notaris.

\section{Penutup}

Berdasarkan pembahasan yang telah diuraikan di atas, maka kesimpulan yang dapat diambil adalah sebagai berikut. Pertama, di dalam membuat Akta Pernyataan Keputusan Rapat Umum Pemegang Saham Notaris harus benar-benar 
mampu menjalankan tugas dan jabatannya dengan baik dan selalu berprinsip hati-hati, karena Akta Pernyataan Keputusan Rapat Umum Pemegang Saham merupakan partij akte, Notaris hanya perlu mencatatkan apa yang dikehendaki oleh para pihak dalam akta tanpa merubah, mengurangi dan menambahkan isi dari akta tersebut. Kedua, adanya klausa proteksi diri dalam suatu Akta Pernyataan Keputusan Rapat Umum Pemegang Saham tidak bisa serta merta menjadi pelindung untuk Notaris ketika terjadi suatu permasalahan dikemudian hari, karena sudah diatur didalam Pasal 65 UUJN bahwa Notaris harus bertanggungjawab atas setiap akta yang dibuat olehnya. Kemudian jika ditinjau dari segi pembuatannya dalam hal ini terpenuhin unsur akta autentik Pasal 1368 KUHPerdata Jo Pasal 38 UUJN serta pengambilan Keputusan Sirkuler di luar RUPS dibuat berdasarkan kententuan Pasal 91 UUPT telah terpenuhi menurut ketentuan tersebut maka akta yang dibuat tersebut merupakan akta autentik serta jika ditinjau dari segi kekuatan pembuktian dari segi Lahiriah, Formil dan Materil akta notaris maka ada atau tidaknya suatu klausul proteksi diri yang dibuat atau dimasukkan dalam akta yang dibuat oleh notaris maka notaris tersebut tidak dapat dimintai pertanggungjawaban jika terjadi suatu kerugian terlebih lagi jika kerugian tersebut ditimbulkan dari para pihak sendiri, karena tugas dari notaris disini hanya diberikan kewenangan hanya sebatas tuntutan dari segi formilnya saja dalam hal ini pembuatan akta tersebut harus sesuai dengan peraturan perundang-undangan yang berlaku

Berdasarkan penelitian yang telah dipaparkan dalam penulisan ini, adapun saran yang dapat diberikan oleh peneliti, yaitu: pertama, dalam pelaksanaan tugas jabatan notaris seyogyanya tetap harus menjalankan prinsip kehati-hatian dalam jabatannya terlebih lagi dalam pembuatan Akta Pernyata Keputasan Rapat Umum Pemegang Saham (PKR) dalam hal ini kepastian dari segi bentuk, isi dan identitas dari para pihaknya harus cermat dalam menilai sebelum dimuat kedalam bentuk akta, jangan sampai apa dokumen yang diberikan ternyata palsu dikarenakan dalam pembuatan akta PKR ini notaris hanya dituntut dari segi formalnya saja bukan dari segi materilnya dalam hal ini dokumen yang dibutuhkan untuk pembuatan akta PKR benar dan telah sesuai dengan apa yang diperlihatkan pada saat itu. Kedua, Notaris dalam pelaksanaan tugas jabatannya harus tetap menambal ilmu hukum pada umumnya dan ilmu kenotariatan pada khususnya sehingga dalam pelaksanaan tugas jabatannya sebagai notaris tidak dikriminalisasi, karena disini notaris hanya memastikan bahwa para penghadap benar-benar berkata demikian pada saat menghadap di notaris namun notaris disini tidak diberi kewenangan untuk membuktikan bahwa apa yang diterangkan penghadap saat itu dapat dinilai benar. 


\section{Daftar Pustaka}

\section{Buku}

Adjie, Habib, Meneropong Khasanah Notaris dan PPAT.

Merajut Pemikiran Dalam Dunia Notarise PPAT, Citra Aditya Bakti, Surabaya, 2010.

Sekilas Dunia Notaris dan PPAT Indonesia, Mandar Maju, Bandung, 2009.

Anshori, Abdul Ghofur, Lembaga Kenotariatan Indonesia Prespektif Hukum dan Etika, UII Press, Yogyakarta, 2009.

Boediarto, M. Ali, Kompilasi Kaidah Hukum Putusan Mahkamah Agung: Hukum Acara Perdata Masa Setengah Abad, Swara Justitia, Jakarta, 2005.

Darus, M. Luthfan Hadi, Hukum Notaris dan Tanggung Jawab Jabatan Notaris, UII Press, Yogyakarta, 2017.

Irwansyah, Lubis, Syahnel Anhar, Lubis Muhammad Zuhdi, Profesi Notaris dan Pejabat Pembuat Akta Tanah, Edisi Kedua, Mitra Wacana Medika, Jakarta, 2018.

Kansil, C.S.T. dan Christine S.T. Kansil, Pokok-Pokok Etika Profesi Hukum, Pradnya Paramita, Jakarta, 1997.

Kansil, Pokok-Pokok Hukum Perseroan Terbatas, Pustaka Sinar Harapan, Jakarta, 1996.

Mulyoto, Pertanggung Jawaban Notaris-PPAT Dalam Menjalankan Tugas Jabatannya, Cakrawala Media, Yogyakarta, 2010.

Nadapdap, Binoto, Hukum Perseroan Terbatas Berdasarkan Undang-Undang No.40 Tahun 2007, Jala Permata Aksara, Jakarta, 2016.

Ranggawidjaya, Rosjidi, Pengantar Ilmu Perundang-Undangan Indonesia, Mandar Maju, Bandung, 1998.

Soekanto, Soerjono, Pengantar Penelitian Hukum, UI Press, Jakarta, 1986.

Yayasan Lembaha Bantuan Hukum Indonesia, Panduan Bantuan Hukum di Indonesia, cet. 2, Yayasan Obor Indonesia, Jakarta, 2007.

\section{Karya Ilmiah}

Yosi Andika Mulyadi, Kekuatan Pembuktian Akta Otentik Yang dibuat dihadapn Notaris dalam perkara pidana", Tesis Pasca Sarjana Magister Kenotariatan Universitas Gadjah Mada Yogyakarta, 2016.

\section{Peraturan Perundang-undangan}

Undang-Undang Nomor 2 Tahun 2014 tentang Perubahan atas Undang-Undang Nomor 30 Tahun 2004 tentang Jabatan Notaris.

Undang-Undang Nomor 40 Tahun 2007 tentang Perseroan Terbatas.

\section{Artikel Elektronik}

https:/ / m.hukumonline.com/berita/baca/lt5d08d3e8227c9/singgung-asas-iactori-incumbit-onus-probandi-i-kpu-bantah-dalil-pemohon-sengketapilpres/. 


\section{Sumber Lain}

Hasil wawancara dengan B. Hendri Susanto Notaris dan PPAT di Yogyakarta, Pada 16 September 2020 pada Pukul 13.00 WIB.

Hasil wawancara dengan Hendrik Budi Untung Notaris dan PPAT di Yogyakarta, Pada 19 September 2020 pada Pukul 09.00 WIB.

Hasil wawancara dengan B. Hendri Susanto Notaris dan PPAT di Yogyakarta, Pada 16 September 2020 pada Pukul 13.00 WIB 